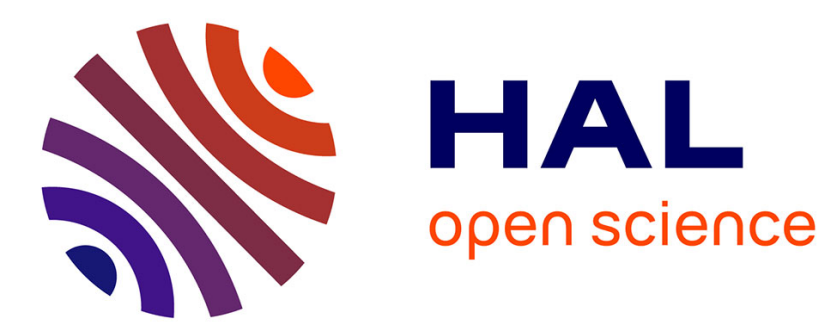

\title{
Signaling the value of a business concept : Evidence from a structural model with Brazilian franchising data
}

Muriel Fadairo, Cintya Lanchimba

\section{To cite this version:}

Muriel Fadairo, Cintya Lanchimba. Signaling the value of a business concept: Evidence from a structural model with Brazilian franchising data. 2012. halshs-00735573

HAL Id: halshs-00735573

https://shs.hal.science/halshs-00735573

Preprint submitted on 26 Sep 2012

HAL is a multi-disciplinary open access archive for the deposit and dissemination of scientific research documents, whether they are published or not. The documents may come from teaching and research institutions in France or abroad, or from public or private research centers.
L'archive ouverte pluridisciplinaire HAL, est destinée au dépôt et à la diffusion de documents scientifiques de niveau recherche, publiés ou non, émanant des établissements d'enseignement et de recherche français ou étrangers, des laboratoires publics ou privés. 
Signaling the value of a business concept :

Evidence from a structural model

with Brazilian franchising data

Muriel Fadairo, Cintya Lanchimba 


\section{GATE Groupe d'Analyse et de Théorie Économique Lyon-St Étienne}

93, chemin des Mouilles 69130 Ecully - France

Tel. +33(0)4 72866060

Fax $+33(0) 472866090$

6, rue Basse des Rives 42023 Saint-Etienne cedex 02 - France

Tel. +33 (0)4 77421960

Fax. +33 (0)4 77421950

Messagerie électronique / Email : gate@gate.cnrs.fr

Téléchargement / Download : http://www.gate.cnrs.fr - Publications / Working Papers 


\title{
Signaling the value of a business concept;
}

\section{Evidence from a structural model with Brazilian franchising data}

\author{
Muriel Fadairo a,b,c*, Cintya Lanchimba ${ }^{a, b, c}$ \\ a Université de Lyon, Lyon, F-69007, France \\ b CNRS, GATE Lyon-St Etienne, UMR $n^{\circ}$ 5824, 69130, Ecully, France \\ c Université de Saint-Etienne, Jean Monnet, F-42023 Saint-Etienne, France
}

\begin{abstract}
Within the wide literature regarding franchising, a few studies were devoted to the adverse selection phenomena in the franchise relationships, and to the signaling explanation of the franchisors' organizational choices.

Previous empirical works concluded that the signaling framework is not well adapted to study franchising.

However, most of the empirical literature has focused on developed countries.

This empirical paper deals with the case of Brazil. We estimate on recent franchising data a structural equation model capturing the simultaneous influences of a valuable business concept. The paper provides evidence that the signaling theory is adequate to understand the organizational choices regarding the ownership structure of franchised networks in emerging markets. The estimation results suggest indeed that the Brazilian franchisors use signaling devices, and that the necessity to signal the value of a business concept affects the organizational choices at the network level.
\end{abstract}

Keywords:

Franchising; Emerging countries; Signaling theory; Structural Equation Modeling.

JEL Classification Numbers: C31; L14.

\footnotetext{
* Corresponding author at: GATE Lyon Saint-Etienne - CNRS, Université Jean Monnet de Saint-Etienne, 6 rue basse des rives, 42023 Saint-Etienne Cedex 2, France.

Tel.: +33 477421 963; fax: +33477421950.

E-mail address: fadairo@univ-st-etienne.fr (M. Fadairo).
} 


\section{Introduction}

The literature dealing with franchising networks emphasizes the relevance of the theory of contracts to understand this major phenomenon. The relationships between franchisors and franchisees are indeed characterized by informational asymmetries, and the devices included in franchise contracts can be studied as a way to confront these asymmetries. More precisely, during the last decades, agency-theoretical explanations in terms of moral-hazards, incentives issues and monitoring costs were the dominant direction in franchising research (e.g., Brickley and Dark, 1987; Brickley et al., 1991; Lafontaine, 1992; Lafontaine and Kaufmann, 1994; Shane, 1996; Combs and Ketchen, 1999; Alon, 2000; Lafontaine and Shaw, 2005; Castrogiovanni et al., 2006; Pénard et al., 2011).

On the contrary, within the wide literature regarding franchising, a few studies were devoted to the adverse selection phenomena in the franchise relationships, and to the signaling explanation of the franchisors' organizational choices. This situation is highlighted by Table 1, constructed from a survey of 18 of the top ranked reviews in Economics and Management ${ }^{1}$.

Table 1

Theoretical frameworks in the literature on franchise data

\begin{tabular}{cc}
\hline Theoretical framework & $\begin{array}{c}\text { Number } \\
\text { of related } \\
\text { articles* }\end{array}$ \\
\hline Agency Theory & 36 \\
Resource Scarcity Theory & 18 \\
Transaction Costs Theory & 4 \\
Signaling Theory & 2 \\
Property Rights Theory & 2 \\
Life Cycle Theory & 1 \\
Other & 26 \\
Not mentioned & 1 \\
\hline
\end{tabular}

*Some articles refer to several theoretical frameworks.

\footnotetext{
${ }^{1}$ Here after in alphabetical order: American Economic Review, Applied Economics, European Economic Review, European Management Review, International Journal of Industrial Organization, Journal of Business Venturing, Journal of Economic Perspectives, Journal of Economics and Management Strategy, Journal of Industrial Economics, Journal of Law and Economics, Journal of Law, Economics and Organization, Journal of Marketing Research, Journal of Retailing, Journal of Small Business Management, Quarterly Journal of Economics, RAND Journal of Economics, Review of Industrial Organization, Strategic Management Journal.
} 
A total of 87 papers regarding franchising have been counted over the period 2000-2012; 67 of them are empirical papers. From this literature two major theoretical frameworks emerge: agency and resources scarcity theories. Adverse selection and signaling problems are only present in two papers.

This orientation of the literature of the past twelve years is consistent with Lafontaine (1993)'s empirical results. Submitting to US data the predictions deriving from Gallini and Lutz (1992)'s seminal theoretical model of signal in franchising, Lafontaine (1993) concludes that signaling theory is not quite appropriate to study franchising.

However, over the last four decades, most of the empirical works have focused on developed countries. Primarily, the literature relates to the United States where, according to Dant et al. (2011), modern franchising dates back to at least 1850 .

A few studies deal with franchising data from emerging countries, while, as mentioned by Welsh et al. (2006), emerging markets represent $80 \%$ of the world's population and offer the most dynamic potential for long-term growth to businesses, in general, and to franchisors, specifically.

The aim of this empirical paper is to test the signaling theory on Brazilian data in order to see if this framework, which is not well adapted to study franchising in developed countries, would be more suited to understand this phenomenon in emerging markets. Indeed, the previous works dealing with franchising in emerging countries highlight deep differences regarding the two groups of countries.

Table 2 presents the few empirical studies devoted to franchising in Latin-America. Using different empirical methods, most of this literature underlines main differences between developed versus emerging countries.

Table 2

Franchising in Latin-America: a survey of the empirical works

\begin{tabular}{ccclll}
\hline Authors & year & $\begin{array}{c}\text { Studied } \\
\text { countries }\end{array}$ & Focus & Method & $\begin{array}{c}\text { Differences } \\
\text { highlighted? }\end{array}$ \\
\hline $\begin{array}{c}\text { Falbe } \\
\text { \& Welsh }\end{array}$ & 1998 & $\begin{array}{c}\text { Mexico } \\
\text { Canada } \\
\text { USA }\end{array}$ & $\begin{array}{l}\text { Executive } \\
\text { perceptions in } \\
\text { success and } \\
\text { failure }\end{array}$ & $\begin{array}{l}\text { Covariance } \\
\text { Factor } \\
\text { analyses }\end{array}$ & Yes \\
$\begin{array}{c}\text { Lafontaine } \\
\text { \& Oxley }\end{array}$ & 2004 & $\begin{array}{c}\text { Mexico } \\
\text { Canada } \\
\text { USA }\end{array}$ & $\begin{array}{l}\text { Contracts } \\
\text { customization }\end{array}$ & Logit Model & No \\
$\begin{array}{c}\text { Dant, } \\
\begin{array}{c}\text { Perrigot } \\
\text { \& Cliquet }\end{array}\end{array}$ & 2008 & USA & Plural form & ANOVA & MANOVA \\
\hline
\end{tabular}




\begin{tabular}{|c|c|c|c|c|c|}
\hline $\begin{array}{l}\text { Cliquet } \\
\& \text { Streed }\end{array}$ & 2011 & $\begin{array}{c}\text { Latin America and } \\
\text { Mexico } \\
\text { Asia } \\
\text { Central and Eastern } \\
\text { Europe } \\
\text { Middle East and } \\
\text { Africa }\end{array}$ & Retail failures & $\begin{array}{l}\text { ANOVA } \\
\text { OLS }\end{array}$ & Yes \\
\hline Michael & 2012 & Latin America & Development & VAR & - \\
\hline
\end{tabular}

This is the case with Falbe and Welsh (1998), dealing with three locations: Mexico, Canada and the United-States. The authors study the franchisors' perceptions regarding the executive and strategic choices which determine success and failures. Streed and Cliquet (2011) address a similar question, and study several emerging countries. They show that a successful expansion abroad requires adaptations to the host market specificities. Dant et al. (2008) underline the differences between Brazil, France, and the United-States regarding the plural form phenomenon. In addition, studying franchising as an economic development strategy for emerging countries, Michael (2012) highlights the differences between franchising in Latin America versus in developed countries. Michael (2012) does not use a comparative approach, but this author highlights the role of franchising in the economic development of Latin America.

Finally, Lafontaine and Oxley (2004)'s empirical work stands as an exception in this literature, because the authors find no main differences comparing franchising in emerging versus developed countries. More precisely, these authors investigate the differences between the contracts offered in Mexico by North American franchisors, and the contracts offered by the same franchisors in their own countries. In this case, the difference is minor. The authors show indeed that there is no customization of the franchise contracts for Mexico; thus, more than $75 \%$ of the sample franchisors require the same franchise fee, whatever the location of the franchisees.

One of the main differences between emerging versus developed countries regarding franchising is that the local franchise system is more recent in the first group of countries. For example, Dant et al. (2008), using data relating to the year 2004, show that in the UnitedStates, there was one franchised outlet for 382.63 inhabitants, in France, one franchised outlet for 1,708.57 inhabitants, while in Brazil, during the same year, there was one franchised outlet for 9,294.74 inhabitants.

This situation suggests that, because the local franchise system is less developed in Brazil, the reputation of Brazilian franchisors is not well established. The theory of signal applied to 
franchising deals precisely with such kind of situation, being particularly suited for the case of young franchising networks.

The following section of the paper presents in greater details this analytical framework, and the deriving testable predictions. Empirical specifications are provided in section 3, regarding Brazilian franchising, and regarding the original sample used in this study. In section 4 , we estimate a structural equation model capturing the specifications related to the analytical context. The results, partially consistent with the theoretical framework, are discussed in section 5. They suggest that the Brazilian franchisors use signaling devices, and that the necessity to signal the quality of a business concept affects the organizational choices. The discussion section concludes this empirical paper, and proposes several ways for future research.

\section{Analytical framework and hypotheses development}

The theory of information, dealing with the organizational remedies to informational asymmetries, constitutes the theoretical background of this paper. More precisely, the paper is based on the signaling theory, focusing on the contexts of adverse selection, and on the seminal model of Gallini and Lutz (1992) regarding signaling in the franchise relationships.

Business-format franchising networks are based on a common trademark and concept, developed by the franchisor, among legally autonomous downstream units. The success, ie the expansion of the network depends on the capacity to attract new franchisees, which is related to the profitability of the concept.

New franchisors with a valuable concept face a problem of asymmetric information. Because they have developed the concept, they possess more information about its profitability than the potential franchisees. This private information causes a problem of adverse selection regarding the type of the franchisors: "good type" with a high value business concept versus "bad type" with a low value one.

When entering a network, the franchisees have to make large investments to specific assets. For this reason, they need to acquire information before making their decisions.

Gallini and Lutz (1992) demonstrate formally that good type franchisors can signal their type, and therefore provide relevant information to the future franchisees (Fig. 1). The signaling devices are organizational and contractual forms that make the franchisor's revenue highly dependent upon the performance of the business concept. These signaling devices are: 
the presence of company-owned outlets in the network in addition with the franchised units, in other words "dual distribution", and a high level of royalty rate.

Two hypotheses derive from this theoretical context:

H1. The proportion of company-owned outlets is positively related to the value of the business concept.

H2. The level of the royalty rate is positively related to the value of the business concept.

In this analytical context we introduce a gradual learning of information, assuming that the first results regarding the profitability of the concept coexist with the signaling period (Fig. 1). For this reason, we formulate the following complementary hypothesis:

H3. The performance of the franchised network during the signaling period is positively related to the value of the business concept.

In the literature on franchising data, the value of the concept, or the brand name value, is often related to the years of the company in business prior to the first franchised unit. This experience allows the upstream firm to develop a profitable concept. This is why we formulate the following hypothesis:

H4. The franchisor's experience is positively related to the value of the business concept.

Figure 1 presents the assumed timing of events:

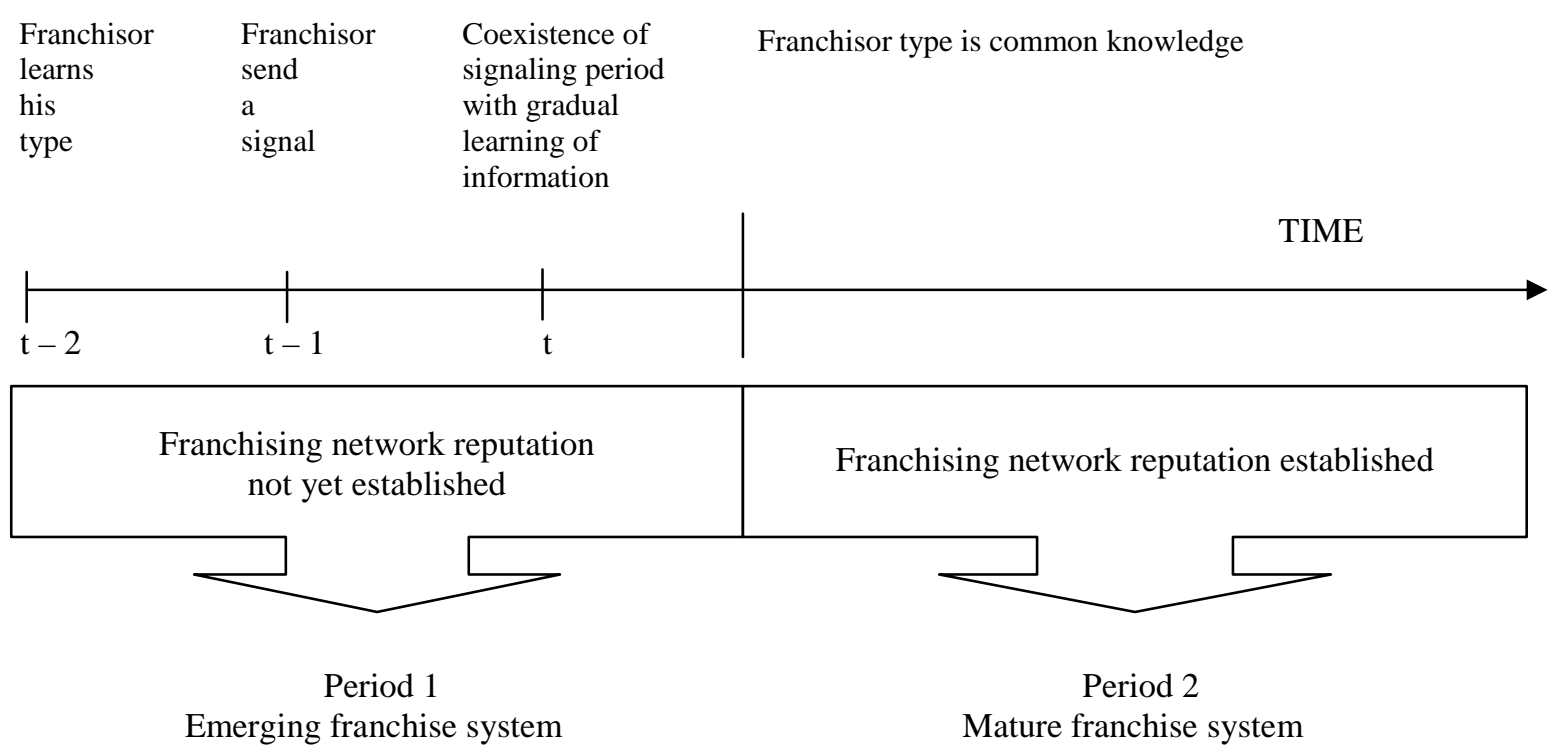

Fig. 1. Timing of events 


\section{Stylized facts, sample and measurements}

\subsection{Brazilian franchising}

The central role of Brazil in the economy of Latin-America is well-known. Brazil stands indeed as the strongest economy of the zone, with several developed sectors such as agriculture, mining, manufacturing and services. This country is a member of the "BRICS" with Russia, India, China, and South Africa ("BRICS"). These emerging economies have several common features: a large population, a vast territory with a continental strategic dimension, a big amount of natural resources, and a remarkable GDP growth during the last ten years.

The emerging position of Brazil appears also regarding franchising. As presented by Figure 2, this country plays a key role in Ibero-American franchising with the highest number of franchised brands of the zone, even more important than Spain, where franchise is though well present. In addition, as shown by Figure 3, the structure of the Brazilian franchise system is dominated by domestic brands (93\%), such as for the developed countries and contrary to the small economies of the zone such as Ecuador, Guatemala, and Uruguay.

However, contrary to the case of developed countries, the Brazilian franchise system is still small regarding the size of the population. This is highlighted by Figures 4-6 which compare for several countries the number of brands, franchised outlets, and the employment in the franchise sector per capita. These Figures suggest that the Brazilian franchise system is indeed emerging, in other words that it is not yet mature.

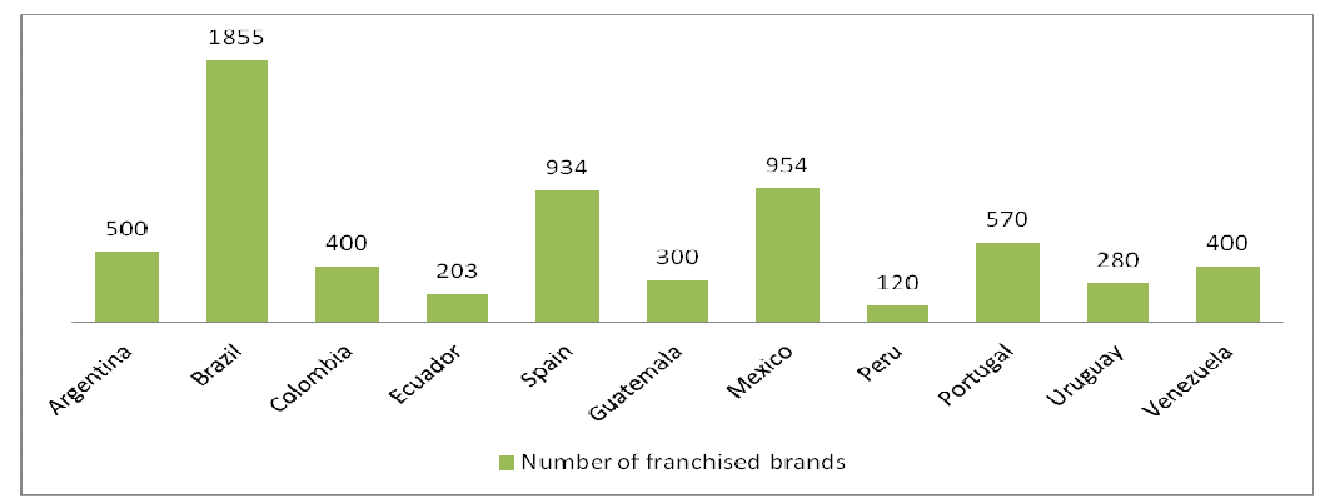

Fig. 2. The key role of Brazil in Ibero-American franchising (Data from: Ibero-American Federation of Franchising - 2010) 


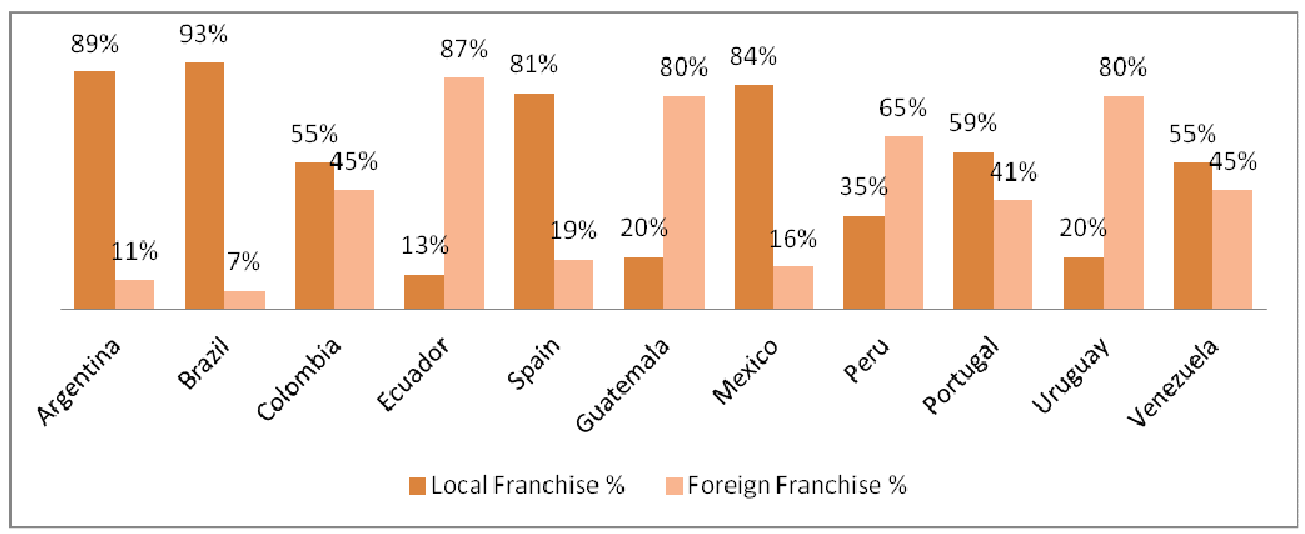

Fig. 3. A Brazilian franchising system based on domestic brands

(Data from: Ibero-American Federation of Franchising - 2010)

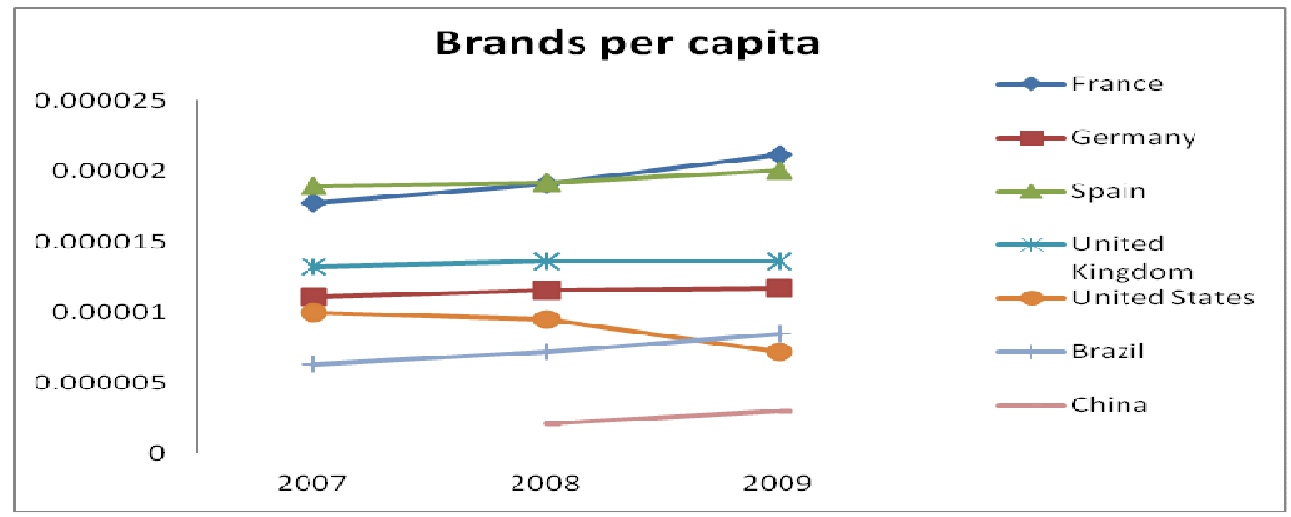

Fig. 4. Emerging Brazilian franchising system (1)

(Data from: Franchise business economic outlook - 2011 and World Bank)

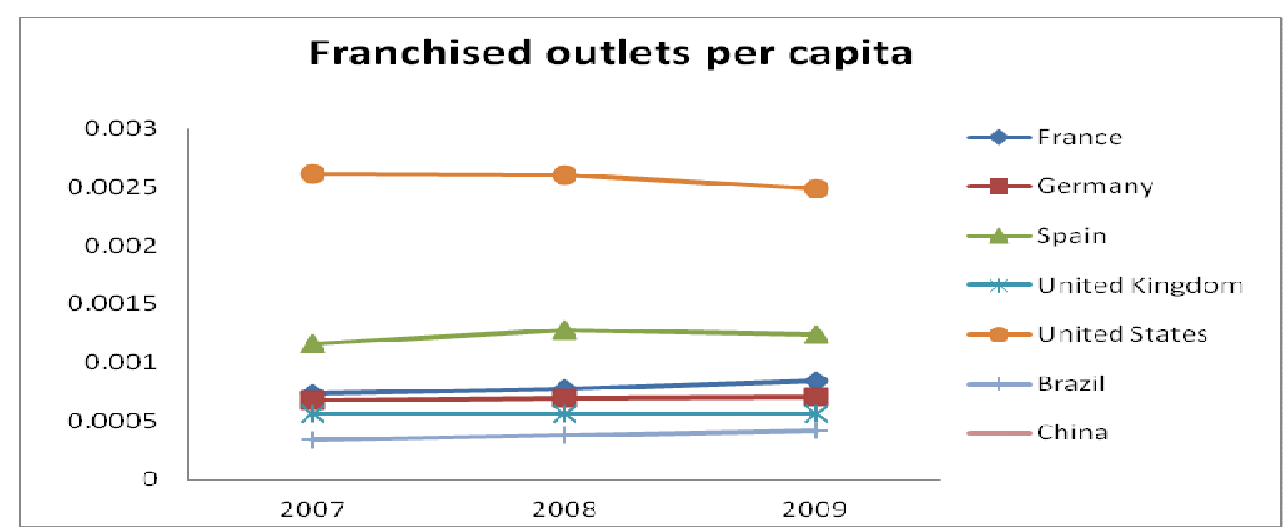

Fig. 5. Emerging Brazilian franchising system (2)

(Data from: Franchise business economic outlook 2011 and World Bank) 


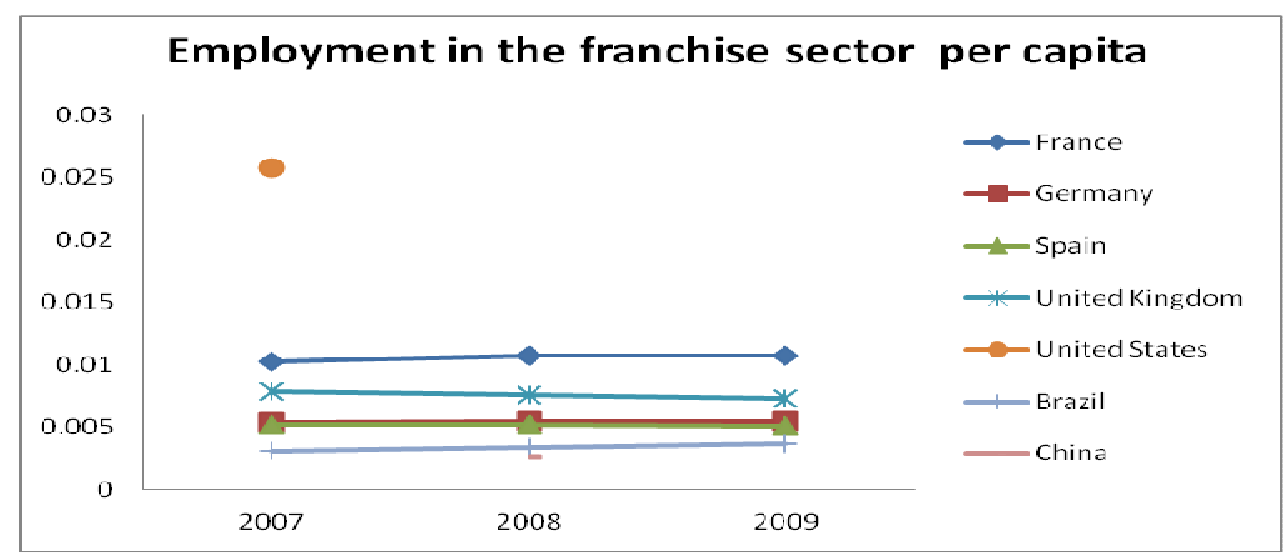

Fig. 6. Emerging Brazilian franchising system (3)

(Data from: Franchise business economic outlook 2011 and World Bank)

\subsection{The Data}

In this study we use cross-sectional data regarding the year 2012 from the Brazilian Franchise Association. The sample consists of 179 franchising networks in a wide range of retail and services sectors.

The study variables derived from the theoretical framework are the proportion of companyowned units, measured as the number of company-owned units divided by the total number of outlets in the network, and the royalty rate, defined as a percentage on the downstream sales accruing to the franchisor. Two control variables are included in this study: the network experience in franchising, referring to the time that the franchisor had to develop his business format, and the franchised network market share, referring to the network performance and defined as the proportion of the network turnover in the whole sector turnover. Table 3 presents the sectors in Brazilian franchising used to construct this variable.

Summary statistics regarding the four study variables are provided by Table 4 .

Table 3

Retail and services sectors in the sample

\begin{tabular}{|l|c|c|}
\hline \multicolumn{1}{|c|}{ Sector } & $\begin{array}{c}\text { Number of franchising } \\
\text { networks }\end{array}$ & Mean turnover* \\
\hline Personal Accessories \& Footwear & 9 & 83333.33333 \\
\hline Feeding & 16 & 97812.5 \\
\hline Bars, restaurants, Pizzerias & 6 & 90833.33333 \\
\hline Drinks, coffee, sweets & 11 & 45000 \\
\hline Beauty, health and natural products & 16 & 77512.5 \\
\hline Communication, Computer, Electronics & 9 & 68333.33333 \\
\hline Construction and Real estate & 12 & 84558.33333 \\
\hline Cosmetics and perfumery & 6 & 44333.33333 \\
\hline
\end{tabular}




\begin{tabular}{|l|c|c|}
\hline Education and Training & 16 & 46200 \\
\hline Entailment, toys and leisure & 2 & 125000 \\
\hline Language Schools & 14 & 49785.71429 \\
\hline Hospitality and tourism & 3 & 273333.3333 \\
\hline Care and Cleaning & 16 & 38731.25 \\
\hline Furniture, decoration and gifts & 10 & 88500 \\
\hline Business services & 14 & 166214.2857 \\
\hline Automotive services & 5 & 53200 \\
\hline Clothing & 14 & 117500 \\
\hline Total & 179 & 82345.2514 \\
\hline
\end{tabular}

* Brazilian Currency: Real - Brazilian data - 2012 
Table 4

Summary Statistics and Correlation Matrix

\begin{tabular}{|c|c|c|c|c|c|c|c|c|c|c|}
\hline & $\mathrm{N}$ & Min & Max & Mean & $\begin{array}{l}\text { Standard } \\
\text { deviation }\end{array}$ & Asymmetry & Kurtosis & 1 & 2 & 3 \\
\hline 1. Experience & 179 & 1,00 & 50,00 & 10,3575 & 9,56677 & 0.102 & 3.045 & & & \\
\hline 2. Company-owned units & 179 & 0,00 & 1,00 & 0,1565 & 0,23278 & 0.712 & 3.094 & $\begin{array}{c}-0,287^{\mathrm{a} * *} \\
(0,000)^{\mathrm{b}}\end{array}$ & & \\
\hline 3. Royalty rate & 179 & 0,00 & 0,50 & 0,0650 & 0,06679 & 0.955 & 4.941 & $\begin{array}{l}-0,065 \\
(0,194)\end{array}$ & $\begin{array}{l}-0,051 \\
(0,248)\end{array}$ & \\
\hline 4. Market share & 179 & 0,00 & 0,60 & 0,0856 & 0,09308 & 0.042 & 4.629 & $\begin{array}{l}-0,135^{*} \\
(0,036)\end{array}$ & $\begin{array}{l}0,125^{*} \\
(0,048)\end{array}$ & $\begin{array}{l}0,125^{*} \\
(0,048)\end{array}$ \\
\hline
\end{tabular}

a Pearson Correlation

b Significance level in brackets.

** Significant correlation at level 0,01 (unilateral).

* Significant correlation at level 0,05 (unilateral) Brazilian data - 2012 
This Table shows the heterogeneity within the sample networks regarding three variables: the proportion of company-owned units, the royalty rates, and the market shares. The networks experience is quite homogenous in the sample, as showed by the means, higher than the standard deviations for this variable.

It is interesting to note that the maximum experience is 50 years, even if the majority of the sample networks have less than a 10 years experience. However, it is worth mentioning that the franchised network with 50 years of experience is not atypical in the sample, because several other networks are close to this situation.

In addition, Table 4 highlights the negative significant correlation between the proportion of company-owned outlets and the franchisor's experience, and between the market share and the franchisor's experience. This second correlation is quite surprising.

The correlation matrix highlights also a positive correlation between the proportion of company-owned units and the network market share.

According to Lafontaine (1993), a negative correlation sign should be expected between the royalty rate and the proportion of company-owned outlets. This is the case here, but the correlation is not significant.

The structural analysis requires the use of normally distributed data. In order to solve the problem of normality highlighted here by the asymmetry of the variables and the kurtosis values, we use a $X^{1 / 2}$ transformation ${ }^{2}$.

\section{Contractual and organizational choices as signaling devices}

\subsection{Method}

In order to submit to data the hypotheses deriving from the signaling theory, we use the structural equation modeling method (SEM) which allows to estimate simultaneous equation models including latent variables. As mentioned by Animesh et al. (2011), Bollen (2011), Squalli et al. (2010), SEM provides rigorous analyses for model fitting.

The value of a business concept can't be inferred directly and constitutes thus the latent variable $(\eta)$ of our econometrical model. According to hypotheses 1 and 2, this variable influences the royalty rate and the proportion of company-owned units in the network, studied here as signals sent by the good type franchisors to the potential franchisees in a context of asymmetric information regarding the latent variable. We assume that, being contractual and organizational choices of the upstream firm, the two signaling devices are stable during the

\footnotetext{
${ }^{2}$ This transformation is preferred to a Log transformation because several study variables are rates.
} 
first period $\left(P_{1}=\{t-1 ; t\}\right)$ where the network reputation is not yet established. For this reason, the signals are defined for $t-1$ and $t$. The network market share evolves continuously and is taken into account at time $t$ as a performance indicator in line with the value of the business concept. The franchisor's experience is the same at time $t$ and $t-1$. This variable is introduced in the econometrical model as a proxy for the quality of the business concept. Both variables (market share, experience) allow distinguishing good type franchisors.

The econometrical model is defined as the following system of structural equations:

$$
\left\{\begin{array}{l}
y_{1}=\alpha_{1}+\lambda_{1} \eta+\varepsilon_{1} \\
y_{2}=\alpha_{2}+\lambda_{2} \eta+\varepsilon_{2} \\
y_{3}=\alpha_{3}+\lambda_{3} \eta+\varepsilon_{3} \\
y_{4}=\alpha_{4}+\lambda_{4} \eta+\varepsilon_{4}
\end{array}\right.
$$

Where,

$\eta$ : refers to the value of the business concept.

$\alpha_{i \in(1,2,3,4)}$ refers to the intercept in the measurement equation.

$\lambda_{i \in(1,2,3,4)}:$ refers to the regression coefficients regarding the effect of the latent variable on $y_{i}$

$y_{i \in(1,2,3,4)}$ refers to the effect indicators of the quality of the business concept $(\eta)$

$\varepsilon_{i \in(1,2,3,4)}:$ refers to the error terms which contain all other influences on $y_{i}$ besides $\eta$.

The model can be re-written in the next path diagram:

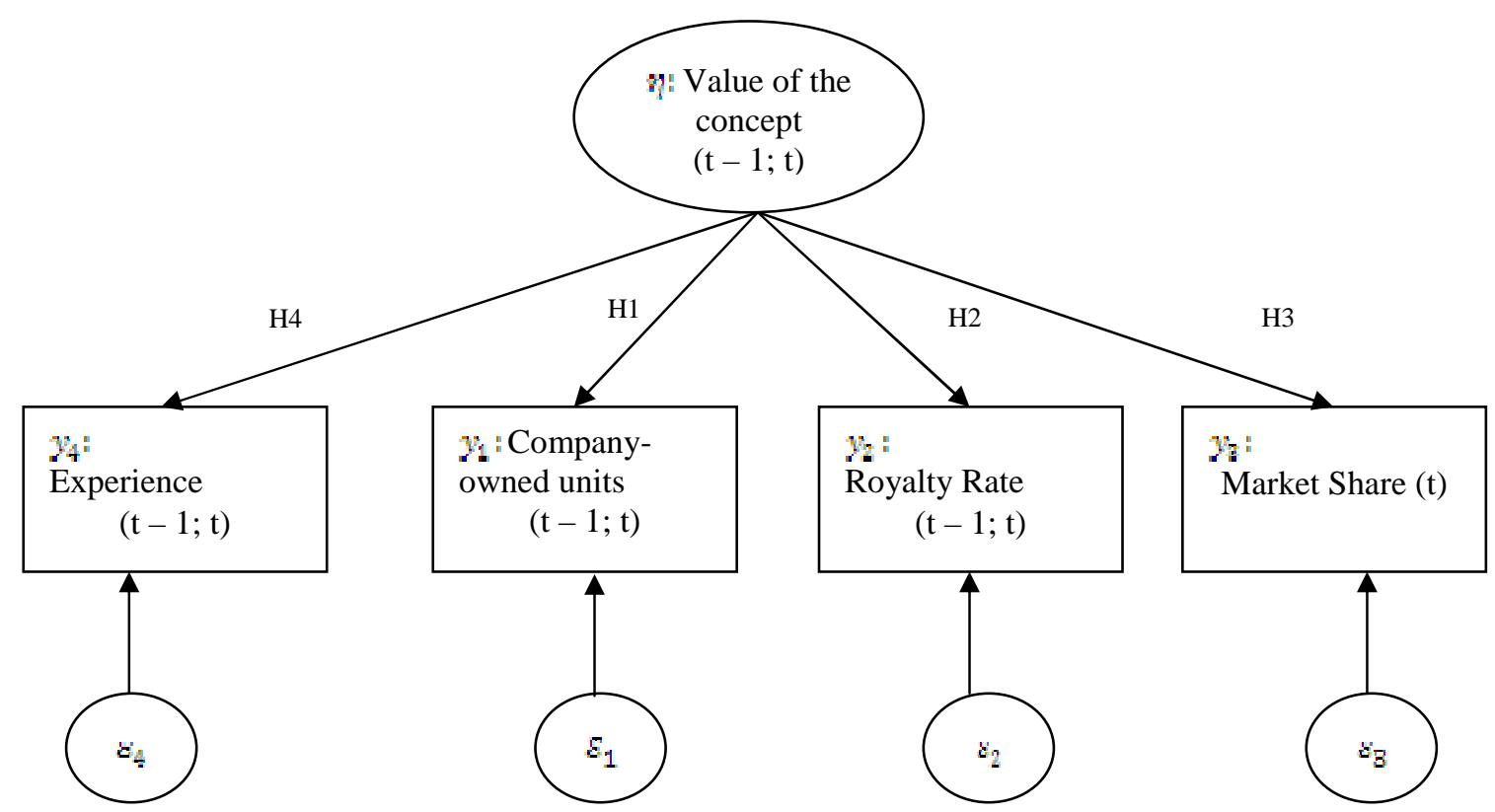

Fig. 7. Path diagram of the structural econometrical model 


\subsection{Results}

Table 5 presents several statistics regarding the overall fit of the estimated model.

Table 5

Fit Statistics

\begin{tabular}{lc}
\hline & Value \\
\hline Likelihood ratio & \\
Model vs. saturated & 1.243 \\
p>chi2 & 0.537 \\
Baseline comparison & \\
Comparative fit index (CFI) & 1.000 \\
Tucker-Levis index (TLI) & 1.087 \\
Size of residuals & \\
Standardized root mean squared residuals & 0.018 \\
Coefficient of determination & 0.575 \\
\hline
\end{tabular}

Brazilian data - 2012

First, like Bollen (2011), we use the likelihood ratio chi-squared test (LR-test) in order to check if the model is adequate in the empirical analysis. This test compares the estimated model with the saturated one. The results show that it is not possible to reject the hypothesis according to which the model is as well as the saturated one. In other words, it is not possible to conclude that there is a missing path in the model specification.

In addition, the modification indices test shows that a change in the specification of the model is not relevant, and that the model is robust ${ }^{3}$.

The comparative fit index and the Tucker-Lewis index indicate that the model has a good fit (values higher than 0.95). These results are confirmed by the standardized root mean squared residuals (lower than 0.08) and the coefficient of determination (57.5\%).

These different and complementary tests allow concluding that the estimated model has a good fit.

\footnotetext{
${ }^{3}$ Results available upon request.
} 
The detailed estimation results are reported in Figure 8, Tables 5 and 7.

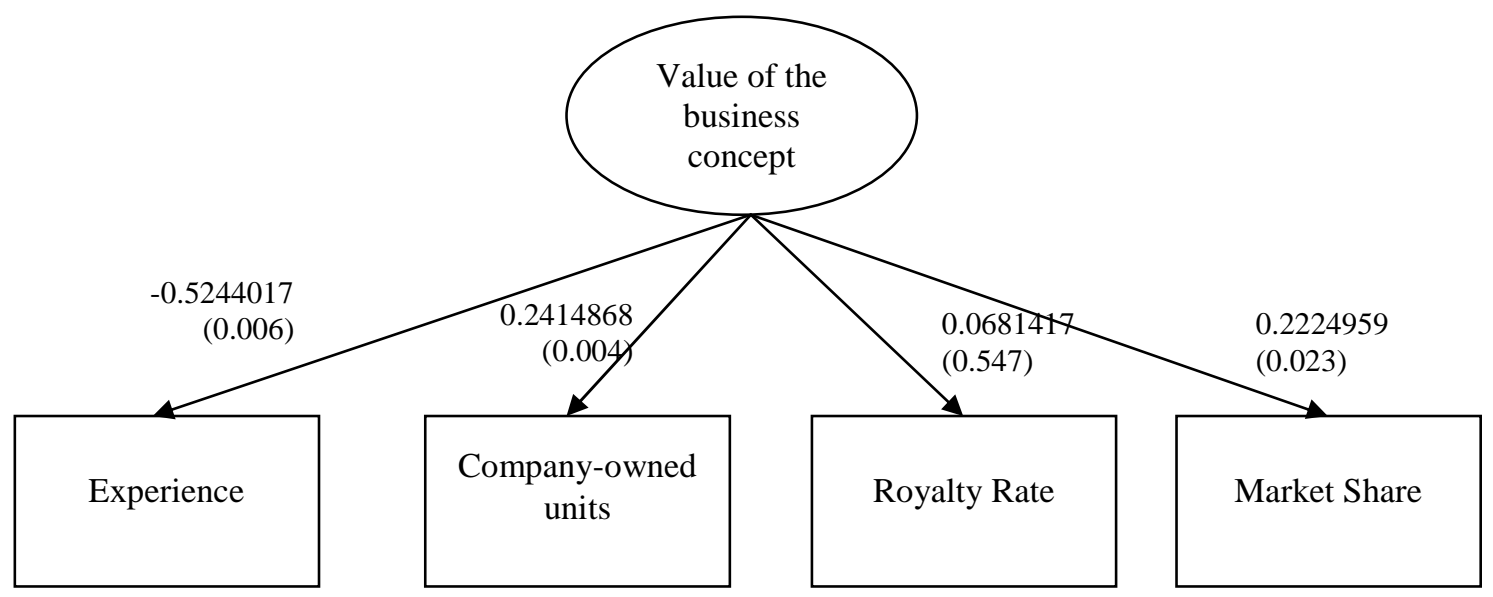

Fig. 8. Empirical results - Brazilian data - 2012

Table 7

Regression coefficients and R-squared

\begin{tabular}{lcccc}
\hline & Coefficient & Std. Err. & P $>|z|$ & R-squared \\
Company-owned units & & & & 0.4784019 \\
Value of concept & 0.6916661 & 0.2414868 & 0.004 & \\
Constant & 1.157124 & 0.0965745 & 0.000 & \\
Royalty rate & & & & 0.0046433 \\
Value of concept & 0.0681417 & 0.1131461 & 0.547 & \\
Constant & 1.752034 & 0.1189998 & 0.000 & \\
Market Share & & & & 0.0495044 \\
Value of the concept & 0.2224959 & 0.9777507 & 0.023 & \\
Constant & 2.051363 & 0.1316854 & 0.000 & \\
Experience & & & & 0.2749972 \\
Value of concept & -0.5244017 & 0.1892347 & 0.006 & \\
Constant & 2.18417 & 0.1375211 & 0.000 & \\
\hline
\end{tabular}

Brazilian data - 2012

These results suggest that, as predicted by $\mathrm{H} 1$, the value of the business concept influences significantly and positively the proportion of company-owned units in Brazilian franchising networks $(\mathrm{p}<0.004)$. The R-squared for this equation is particularly high regarding crosssectional data (47.8\%). This empirical result supports the signaling explanation.

On the contrary, the estimations reveal that the value of the concept has no significant influence on the royalty rate, which does not support $\mathrm{H} 2$.

Consistent with $\mathrm{H} 3$, the value of the concept impacts significantly and positively the market share $(\mathrm{p}<0.023)$. 
Finally, as predicted, the franchisor's experience in business prior to the first franchised unit is empirically related to the value of the business concept, but the negative sign is reverse to the predicted one. This result confirms the first empirical outcomes regarding the correlation matrix and the negative correlation between the franchisor's experience and the network market share.

\section{Discussion}

This empirical paper estimates a structural equation model on recent Brazilian franchising data. The method allows studying the simultaneous influence of the value of a business concept on organizational and contractual signaling devices, and on the market share of the franchised network, taking into account the relationship between the value of the concept and the franchisor's experience.

The empirical results show that the estimated model has a good fit, and they provide several interesting outcomes regarding franchising in emerging markets.

First, the results suggest that the organizational choices of local franchisors in emerging markets differ from what has been observed so far regarding franchising in developed countries. More precisely, the paper provides evidence that signaling may motivate the organizational choices in emerging local systems. This result is particularly interesting knowing that most of the literature dealing with franchising in the framework of the theory of contracts focuses on the agency explanation.

Two signaling devices were identified in the seminal model of Gallini and Lutz (1992) concerning signaling in franchise networks: the royalty rate and the proportion of companyowned units. In terms of signal, these two devices may be considered as substitutes. Our results suggest that this is not the case, and that the franchisors use the organizational form of the network (dual distribution) rather than the contractual design (high level of royalty rate) to signal the value of their business concept to potential franchisees.

As predicted, the value of the concept influences positively the market share during the signaling period. However, the results regarding the franchisor's experience are unexpected. Instead of a positive relationship between the franchisor's years in business prior to the development of the franchised chain, a negative one is estimated.

The explanation may rely on the context of this study, which deals with an emerging market. It is indeed relevant to suggest that in Brazil, the business environment being 
particularly dynamic, the maturity time of a valuable business concept is lower than in developed countries.

Moreover, our results suggest that local business owners with a valuable concept settle quickly their franchised network into a very dynamic environment where consequently competition is strong and where market shares are being distributed. In this context, the "good type" franchisor is both the one who possesses a profitable concept, and who is able to impose it quickly in the form of a franchised network.

Several limitations of our study have to be mentioned, interesting for further researches.

First, our empirical investigation is limited by the cross sectional data. The availability of panel datasets regarding emerging countries would allow consideration of the evolutions, especially when the franchise system enters its mature phase.

In addition, it would be interesting to extend the analysis to other Latin American countries with different levels of economic development.

Finally, our results show that the signaling theory is adequate to understand the organizational choices regarding the ownership structure of franchised networks in emerging markets. However the issue concerning the required level of company-owned units is not addressed here. Further empirical researches could deal with this issue and provide evidence regarding the proportion of company-owned units required to act as an efficient signaling device.

\section{Acknowledgements}

We wish to thank the National Secretary of Higher Education, Science, Technology and Innovation of Ecuador for its financial support.

\section{References}

Alon I. 2000. The use of franchising by U.S.-based retailers. Journal of Small Business Management. 39: 111-122.

Animesh A., Pinsonneault A., Yang S. and Oh W, 2011. An odyssey into virtual worlds: exploring the impacts of technological and spatial environments on intention to purchase virtual products, Mis Quarterly, 35: 789-810.

Arias, B., 2008. Desarrollo de un ejemplo de análisis factorial confirmatorio con LISREL, AMOS y SAS. In M. A. Verdugo, M. Crespo, M. Badía, \& B. Arias (Coords) Metodología en la investigación sobre discapacidad. Introducción al uso de las ecuaciones estructurales. Salamanca: INICO. ISBN: 978-84-691-5852-4.

Bollen K., 2011. Evaluating effect, composite, and causal indicators in structural equation models. Mis Quarterly, 35: 359-372. 
Brickley JA, Dark FH, Weisbach MS. 1991. The Economic Effect of Franchise Termination Laws. Journal of Law and Economics. 34: 101-132.

Brickley JA, Dark FH. 1987. The Choice of Organizational Form: The Case of Franchising. Journal of Financial Economics. 18: 401-420.

Castrogiovanni GJ, Combs JG, Justis RT. 2006. Shifting Imperatives: An Integrative Resource Scarcity and Agency Reasons for Franchising. Entrepreneurship Theory and Practice. 30: 23-40.

Combs JG, Ketchen DJ. 1999. Can Capital Scarcity Help Agency Theorry Explain Franchising? Revisiting the Capital Scarcity Hypothesis. Academic Management Journal. 42: 196-207.

Dant R., Grünhagen M., Windsperger J., 2011. Franchising Research Frontiers for the Twenty-First Century. Journal of Retailing, 87: 253-268

Dant R., Perrigot R., Cliquet G., 2008. A Cross-Cultural Comparation of the Plural Forms in Franchise Networks: United States, France and Brazil. Journal of Small Business Management, 46: 286-311.

Falbe, Welsh, 1998, Nafta and franchising: A comparison of Franchisor Perceptions of Characteristics Associated with Franchisee success and Failure in Canada, Mexico, and the United states. Journal of Business Venturing. 13: 151-171

Gallini N. and Lutz N, 1992. Dual Distribution and Royalty Fees in Franchising, Journal of Law, Economics, \& Organization, 8: 471-501

Ibero-American Federation of Franchising, 2010 Statistics data http://www.portalfiaf.com/english/in_statistics.asp, Access on 23 July 2012.

Squalli J., Wilson K., Hugo S., 2010, An analysis of market access, Applied Economics, 42: 1833-1844.

European Franchise Federation, 2011, Franchising: a vector for economic growth in Europe. http://www.efffranchise.com/IMG/pdf/Franchising_A_vector_for_Economic_Growth in_Europe_-_2011_v472011.pdf, 2011. Access on 17 July 2012.

Lafontaine F, 1993. Contractual Arrangements as Signaling Devices: Evidence from Franchising. Journal of Law, Economics, \& Organization, 9: 256-289

Lafontaine F, Kaufmann P. 1994. The Evolution of Ownership Patterns in Franchise Systems. Journal of Retailing, 70: 97-113.

Lafontaine F. 1992. Agency Theory and Franchising; Some Empirical Results. RAND Journal of Economics. 23: 263-283.

Lafontaine F. and Oxley G., 2004. International Franchising Practices in Mexico: Do Franchisors customize their contracts. Journal of Economics and Management Strategy, 13: $95-123$

Lafontaine, F, Shaw K. 2005. Targeting managerial control: evidence from franchising. RAND Journal of Economics. 36: 131-150.

Michael S., 2012. Can Franchising be an Economic Development Strategy for Developing Nations? An empirical investigation. ISOF Conference.

Pénard T, Raynaud E, Saussier, S. 2011. Monitoring Policy and Organizational Forms in Franchised Chains. International Journal of the Economics of Business. 18: 399-417.

PricewaterhouseCoopers, 2011 Franchise business economic outlook, http://www.franchise.org/uploadedFiles/Franchise/20Business/20Outlook/20Report/2020 11/20final.pdf, 2011. Access on 13 July 2012.

Shane S. 1996. Hybrid organizational arrangements and their implications for firm growth and survival: A Study of new franchisors. Academy of Management Journal. 39: 216234. 
Streed O., Cliquet G., 2011. International Market Expansion of Retail Networks: Governance Modes and Failures in Emerging Countries. EMNet Conference.

Welsh D., Alon I., Falbe C., 2006. An Examination of International Retail Franchising in Emerging Markets. Journal of Small Business Management, 44: 130-149. 